\title{
Faktor Yang Mempengaruhi Minat Mahasiswa Program Studi Periklanan Dalam Matakuliah Komputer Desain Grafis I
}

\author{
Jusuf Fadilah $^{1}$, Dina Andriana ${ }^{2}$, Widarti $^{3}$ \\ Program Studi Periklanan, jusuf.jff@bsi.ac.id \\ Program Studi Periklanan, dina.daa@bsi.ac.id \\ Program Studi Periklanan, widarti.wdr@bsi.ac.id
}

\begin{abstract}
Abstrak
Penelitian ini bertujuan untuk mengetahui faktor apa sajakah yang mempengaruhi minat mahasiswa dalam matakuliah Komputer Desain Grafis I. Faktor minat mahasiswa didasarkan pada faktor Internal yakni 1) rasa tertarik, 2) perhatian, 3) prilaku, dan Faktor Eksternal yakni 1) fasilitas dan 2) peran dosen. Penelitian ini merupakan penelitian deskriptif dengan menggunakan metode survey. Subyek dalam penelitian ini, yaitu mahasiswa UBSI Program Studi Periklanan angkatan 2018-2019 berjumlah 100 orang, dengan instrumen yang digunakan berupa angket. Uji validitas menggunakan rumus Product Moment, sedangkan uji reliabilitas instrumen menggunakan rumus Alpha Cronbach. Dalam Uji validitas menghasilkan koefisien sebesar 0,897 dan koefisien reliabilitas sebesar 0,765. Dalam menganalisis data menggunakan teknik deskriptif kuantitatif. Hasil penelitian diperoleh faktor yang mempengaruhi minat mahasiswa program studi Periklanan dalam matakuliah Komputer Desain Grafis I yaitu faktor eksternal sebesar 59\% lebih tinggi dari faktor internal yaitu sebesar $41 \%$. Sedangkan dari data perfaktor, faktor peran dosen berada lebih tinggi yakni sebesar $31 \%$, diikuti faktor fasilitas $28 \%$, faktor rasa tertarik sebesar $15 \%$, faktor prilaku sebesar $15 \%$ dan faktor perhatian lebih rendah yakni sebesar $11 \%$.
\end{abstract}

Kata kunci: Mahasiswa, Periklanan, Komputer Desain Grafis I

\begin{abstract}
This study aims to determine what factors influence student interest in the subject of Computer Graphic Design I. Student interest factors are based on internal factors, namely 1) interest, 2) attention, 3) behavior, and external factors, namely 1) facilities and 2) the role of the lecturer. This research is a descriptive study using a survey method. The subjects in this study were 100 students of the UBSI Advertising Study Program class 2018-2019, with the instrument used in the form of a questionnaire. The validity test uses the Product Moment formula, while the instrument reliability test uses the Cronbach Alpha formula. In the validity test produces a coefficient of 0.897 and a reliability coefficient of 0.765. In analyzing the data using quantitative descriptive techniques. The results showed that the factors that influence the interest of students in the Advertising study program in the Computer Graphic Design I course are external factors by 59\% higher than internal factors, namely by 41\%. Meanwhile, from the performance factor data, the lecturer role factor was higher at $31 \%$, followed by the facilities factor of $28 \%$, the attraction factor by $15 \%$, the behavior factor by $15 \%$ and the attention factor was lower at $11 \%$.
\end{abstract}

Keywords: Student, Advertising, Computer Graphic Design I

SSN: 2355-0287, E-ISSN: 2549-3299

http://ejournal.bsi.ac.id/ejurnal/index.php/jika 


\section{PENDAHULUAN}

Komputer Desain Grafis I merupakan salah satu matakuliah praktikum yang ada dalam program studi Periklanan fakultas komunikasi dan bahasa Universitas Bina Sarana Informatika di semester awal, dalam matakuliah ini mahasiswa diajarkan untuk mengolah image/gambar berupa foto untuk diolah baik dari segi manipulasi objek, pewarnaan maupun tipografi yang akan digunakan dalam desain.

Pada matakuliah Komputer Desain Grafis I mahasiswa diajarkan mengolah foto dengan bantuan salah satu software desain yaitu software Adobe Photoshop CC. Photoshop merupakan salah satu aplikasi perangkat lunak untuk editor foto atau gambar yang di keluarkan Adobe Systems dikhususkan untuk pengeditan foto atau gambar dan pembuatan efek, atau biasa disebut layer style. Software Adobe Photoshop banyak digunakan oleh fotografer digital dan perusahaan iklan.

Selain memiliki fitur yang mudah untuk di pahami, photoshop juga memiliki beberapa fitur unggulan yang dapat bekerja secara maksimal, dan juga dapat mensuport beberapa file, sehingga bagi seorang desain grafis hal ini merupakan salah satu syarat yang wajib ada untuk masuk ke dunia desain grafis, karena photoshop dengan segala fasilitasnya sangat cocok bagi seorang desain grafis.

Tool yang ada pada photoshop merupakan alat yang dapat membantu pengguna dalam mengedit. Adobe Photoshop memiliki serkitar 59 tool yang dapat digunakan oleh pengguna. Tool- tool ini terdiri dari berbagai macam tool dengan kegunaan yang spesifik.

Sebenarnya fungsi utama dari Adobe Photoshop hanyalah untuk aplikasi pengedit foto ataupun gambar dengan tipe raster atau bitmap. Namun sebagai aplikasi pengedit gambar, fungsi
Photoshop dapat dijabarkan lebih khusus lagi, yaitu untuk mempercantik gambar, merekayasa gambar, dan membuat desain gambar.

Fungsi Photoshop untuk mempercantik gambar yaitu dengan cara menghaluskan atau objek, dimana hal ini dilakukan agar gambar tersebut terlihat lebih menarik dan indah. Fungsi Photoshop juga untuk merekayasa gambar yaitu dengan cara merubah tampilan ataupun menggabungkan gambar-gambar yang berbeda agar gambar tersebut terlihat seperti gambar asli dan seringkali dapat menipu mata yang melihatnya. Dan fungsi Photoshop untuk membuat desain gambar yaitu dengan cara menciptakan objek baru seperti logo, brosur, spanduk, dan poster. (Zakaria, 2020)

Berdasarkan fungsi-fungsi yang ada dalam photosop itulah maka banyak mahasiswa yang tertarik/berminat untuk mempelajarinya di kelas/laboratorium. Kondisi sarana dan prasaran untuk perkuliahan Komputer Desain Grafis I di UBSI sangatlah memadai. Laboratorium multimedia yang ber AC membuat perkuliahan tidak panas, spek komputer desain yang memadai dan bagus sehingga memudahkan mahasiswa dalam mempelajari dan mempraktekan hal-hal yang diajarkan.

Matakuliah Komputer Desain Grafis I sangat diminati oleh mahasiswa periklanan, namun dengan banyaknya peminat dari mahasiswa tersebut tidak didukung oleh tenaga pengajarnya. Dosen yang mengajar matakuliah Komputer Desain Grafis I masih kurang di UBSI padahal peminatnya banyak.

Dengan besarnya faktor minat mahasiswa periklanan angkatan 2018-2019 dalam matakuliah Komputer Desain Grafis I, maka nilai yang dihasilkan oleh mahasiswa tersebut akan tinggi. Tapi, terkadang dengan minat mahasiswa yang 
begitu besar, nilai yang dihasilkan malah menjadi rendah. Jadi faktor yang mempengaruhi mahasiswa itu sangat berpengaruh dalam matakuliah Komputer Desain Grafis I.

Peneliti ingin mengetahui seberapa besar faktor yang mempengaruhi minat mahasiswa prodi Periklanan dalam mata kuliah Komputer Desain Grafis I. Sejauh ini belum ada penelitian yang mengkaji tentang minat mahasiswa prodi Periklanan terhadap mata kuliah Komputer Desain Grafis I.

\section{KAJIAN LITERATUR Hakikat Minat}

Minat adalah salah satu unsur kepribadian yang memegang peranan dalam mengambil keputusan masa depan. Minat merupakan kecenderungan dalam diri individu untuk tertarik pada suatu objek atau menyenangi sesuatu objek. (Suryosubroto, 1988)

Seseorang yang minatnya tinggi terhadap ilmu pengetahuan, ia akan suka mempelajari ilmu itu. Jika tidak mempunyai minat terhadap sesuatu, maka akan mengakibatkan ia tidak punya perhatian terhadapnya dan karena itu ia tidak akan berhasil dalam mempelajarinya. Minat ada yang muncul dengan sendirinya (minat dengan sendirinya $=$ minat spontan), ada yang muncul karena dibangkitkan dengan usaha atau sengaja.

Apabila seseorang mempunyai rasa ketertarikan pada suatu obyek maka seseorang tersebut akan senang mempelajari suatu obyek tersebut. Minat atau interest bisa berhubungan dengan daya gerak yang mendorong kita cenderung atau merasa tertarik pada orang, benda atau kegiatan ataupun bisa berupa pengalaman yang efektif yang dirangsang oleh kegiatan itu sendiri. Dengan kata lain, minat dapat menjadi penyebab kegiatan dan penyebab partisipasi dalam kegiatan. (Abror, 1993)

Minat merupakan kecenderungan dalam diri individu untuk tertarik pada suatu objek atau menyenangi sesuatu objek. Sehingga apabila seseorang mempunyai rasa ketertarikan pada suatu obyek maka seseorang tersebut akan senang mempelajari suatu obyek tersebut. (Suryosubroto, 1988)

Minat merupakan sumber motivasi yang mendorong orang untuk melakukan apa yang mereka inginkan bila mereka bebas memilih. Bila mereka melihat bahwa sesuatu akan menguntungkan, mereka merasa berminat. Ini kemudian mendatangkan kepuasan, bila kepuasan berkurang dan minatpun berkurang. (Hurlock, 1978)

Minat adalah sesuatu pemusatan perhatian yang tidak disengaja yang terlahir dengan penuh kemauannya dan yang tergantung dari bakat dan lingkungannya. Jadi minat muncul apabila individu tersebut terhadap sesuatu yang dirasakan menarik dan bermakna serta dibutuhkan oleh individu. (Sujanto, 2008)

Minat yaitu kecenderungan yang tetap untuk memperhatikan dan mengenang beberapa kegiatan. Kegiatan yang diminati seseorang, diperhatikan terusmenerus yang disertai dengan rasa senang. (Slameto, 2010)

Minat merupakan suatu perangkat mental yang terdiri dari suatu campuran dari perasaan, harapan, pendirian, prasangka, rasa takut, atau kecenderungankecenderungan lain yang mengarahkan individu kepada suatu pilihan tertentu. (Mappiare, 1994)

Dari pengertian tersebut kita memperoleh kesan bahwa minat itu, sebenarnya mengandung unsur-unsur: kognisi (mengenal), emosi (perasaan), dan konasi (kehendak). Dan oleh sebab itu, minat dapat dianggap sebagai respon yang sadar; 
sebab kalau tidak demikian, maka minat tak akan mempunyai arti apa-apa. Unsur kognisi, dalam arti minat itu didahului oleh pengetahuan dan informasi mengenai obyek yang dituju oleh minat tersebut. Unsur emosi, karena dalam pertisipasi atau pengalaman itu disertai dengan perasaan tertentu (biasanya perasaan senang). Sedangkan unsur konasi merupakan kelanjutan dari kedua unsur tersebut yaitu yang diwujudkan dalam bentuk kemauan dan hasrat untuk melakukan suatu kegiatan.

\section{Faktor-Faktor Yang Mempengaruhi Minat}

Adapun faktor-faktor yang mempengaruhi minat menurut Crow and Crow adalah :

a. Faktor Pendorong Dari Dalam (The Factor Inner Urge)

Adalah rangsangan yang datang dari lingkungan/ruang lingkup yang sesuai dengan keinginan/kebutuhan seseorang akan mudah menimbulkan minat: cenderung terhadap belajar, dalam hal ini seseorang mempunyai hasrat ingin tahu terhadap ilmu pengetahuan.

b. Faktor Motif Sosial (The Factor of Social Motif)

Adalah minat seseorang terhadap obyek/suatu hal, disamping hal dipengaruhi oleh faktor dari dalam diri manusia juga dipengaruhi oleh motif sosial, misalnya: seseorang berminat pada prestasi tertinggi agar dapat status sosial yang lebih tinggi pula.

c. Faktor Emosi (Emosional Factor)

Faktor perasaan dan emosi mempunyai pengaruh terhadap subyek misalnya: perjalanan sukses yang dipakai seseorang dalam sesuatu kegiatan tertentu dapat membangkitkan perasaan senang dan dapat menambah semangat/kuatnya minat dalam kegiatan tersebut. (Gunarto, 2007) Minat dipengaruhi oleh 2 faktor:

a. Faktor dari dalam (intrinsik) yaitu berarti bahwa sesuatu perbuatan memang diinginkan karena seseorang senang melakukannya. Disini minat datang dari dalam diri orang itu sendiri. Orang senang melakukan perbuatan itu demi perbuatan itu sendiri. Seperti: rasa senang, mempunyai perhatian lebih, semangat, motivasi dan emosi.

b. Faktor dari luar (ekstrinsik) bahwa suatu perbuatan dilaksanakan atas dorongan/ pelaksanaan dari luar. Orang melakukan perbuatan itu karena ia didorong/dipaksa dari luar. Seperti: lingkungan, orang tua, guru. (Haditono, 2007)

Minat mengandung unsur-unsur:

a. Kognisi (Mengenal)

Minat itu didahului oleh pengetahuan dan informasi mengenai obyek yang dituju oleh minat tersebut.

b. Emosi (Perasaan)

Unsur emosi, karena dalam partisipasi atau pengalaman itu disertai dengan perasaan tertentu (biasanya perasaan senang).

c. Konasi (Kehendak)

Merupakan kelanjutan dari kedua unsur tersebut yaitu yang diwujudkan dalam bentuk kemauan dan hasrat untuk melakukan suatu kegiatan, termasuk kegiatan yang diselenggarakan disekolah. (Abror, 1993)

Dari beberapa pendapat diatas diidentifikasikan unsur-unsur minat sebagai berikut :

a. Adanya kecenderungan untuk kebutuhan dalam jiwa seseorang (unsur kognitif).

b. Adanya pemusatan perhatian individu.

c. Adanya rasa senang pada individu, baik keinginan untuk mengetahui, melaksanakan maupun membuktikan lebih lanjut.

d. Adanya pemusatan pikiran, perasaan, dan kemauan atau pemusatan perhatian terhadap suatu obyek tersebut menarik perhatian. 
Berdasarkan identifikasi unsur dan faktor yang mempengaruhi minat dapat disimpulkan bahwa minat merupakan kecenderungan dalam individu untuk tertarik pada suatu obyek, aktivitas dan merasa senang untuk terlibat dalam aktivitas tersebut yang dilakukan dengan kesadaran diri sendiri. Minat sangat penting peranannya dalam kehidupan seseorang, minat yang membantu penyesuaian pribadi dan sosial seseorang perlu ditemukan dan dipupuk. Untuk membedakan minat dengan kesenangan sementara.

\section{Program Studi Periklanan}

Program studi Periklanan merupakan salah satu Program Studi Diploma III yang pada awalnya berada dalam Akademi Komunikasi Bina Sarana Informatika, saat ini tetap di pertahankan setelah adanya penggabungan akademiakademi di bawah Yayasan Bina Sarana Informatika menjadi Universitas Bina Sarana Informatika.

Pada Universitas Bina Sarana Informatika Program Studi Periklanan berada di bawah Fakultas Ilmu Komunikasi dan Bahasa. Program Studi Periklanan menerapkan kurikulum dengan sistem pembelajaran berbasis teknologi informasi dan multimedia yang berorientasi menumbuhkembangkan cara berpikir kreatif dan penguasaan keterampilan dibidang desain grafis periklanan serta perancangan strategi komunikasi pemasaran bagi mahasiswa. Lulusan Program Studi Periklanan dipersiapkan untuk menempati posisi di biro periklanan sebagai; Account Executive/Planner, Art Director, Copywriter, Media Planner and Buyer, Graphic Designer, Animator dan Fotografer.

(Periklanan, 2017)

\section{Matakuliah Komputer Desain Grafis I}

Matakuliah Komputer Desain Grafis I merupakan salah satu matakuliah inti keilmuan prodi yang harus ditempuh oleh mahasiswa. Mata kuliah ini memberikan materi untuk penguasaan software berbasis image yaitu Adobe Photoshop $\mathrm{CC}$ untuk merancang digital imaging sebagai dasar dalam merancang seni desain komunikasi visual. (Periklanan, 2017)

\section{METODE PENELITIAN Metode Penelitian}

Penelitian ini merupakan penelitian deskriptif kuantitatif. Penelitian deskriptif digunakan untuk mendeskripsikan atau menggambarkan data yang telah terkumpul sebagaimana adanya (Sugiyono, 2014).

Metode yang digunakan pada penelitian ini adalah survei. Studi survei merupakan salah satu pendekatan penelitian yang pada umumnya digunakan untuk pengumpulan data yang luas dan banyak (Arikunto, 2013). Sedangkan teknik pengumpulan data yang digunakan dalam penelitian ini menggunakan instrumen berupa angket. Kuesioner (angket) merupakan teknik pengumpulan data yang dilakukan dengan cara memberi seperangkat pertanyaan atau pernyataan tertulis kepada responden untuk dijawabnya (Sugiyono, 2014).

\section{Waktu dan Lokasi Penelitian}

Penelitian ini di lakukan di Universitas Bina Sarana Informatika, penelitian ini dilakukan di Fakultas Komunikasi dan Bahasa Program Studi Periklanan angkatan 2018-2019 dan dilaksanakan pada bulan Agustus 2020-Februari 2021.

\section{Definisi Operasional Variabel Penelitian}

Berdasarkan rumusan masalah dan batasan masalah yang ditetapkan, variabel dalam penelitian ini merupakan variabel tunggal yaitu minat mahasiswa terhadap mata kuliah Komputer Desain Grafis I. 
Untuk mencapai tujuan penelitian, perlu diketahui terlebih dahulu variabel penelitiannya. Yang dimaksud dengan variabel yaitu segala yang akan menjadi objek penelitian atau apa saja yang menjadi titik perhatian dari suatu penelitian (Arikunto, 2013). Guna memperjelas variabel penelitian, perlu dikemukakan definisi operasional dari veriabel. Minat merupakan perangkat mental yang menggerakkan mahasiswa dalam matakuliah Komputer Desain Grafis I. Dalam penelitian ini, minat mahasiswa yang terdiri dari 3 faktor yaitu rasa tertarik, perhatian, perilaku, yang diukur menggunakan angket yang disebarkan oleh responden dengan jawaban "Setuju", "Tidak Setuju", "Sangat Setuju" dan "Sangat Tidak Setuju".

\section{Populasi dan Sampel Penelitian Populasi Penelitian}

Populasi adalah keseluruhan subjek penelitian (Arikunto, 2013). Dalam penelitian ini populasinya adalah mahasiswa Program Studi Periklanan angkatan 2018-2019 Fakultas Komunikasi dan Bahasa yang mengambil mata kuliah Komputer Desain Grafis I sejumlah 100 mahasiswa.

\section{Sampel Penelitian}

Sampel merupakan sebagian atau wakil populasi yang diteliti (Arikunto, 2013). Dinamakan penelitian sampel apabila kita bermaksud untuk menggeneralisasikan hasil penelitian sampel. Yang dimaksudkan menggeneralisasikan yaitu mengangkat kesimpulan penelitian sebagai sesuatu yang berlaku bagi populasi.

Dalam penelitian ini, peneliti menggunakan sampel acak/random. Karena untuk menghemat biaya, waktu dan tenaga maka peneliti memilih untuk menggunakan sampel acak/random. Dalam penelitian ini, sampel yang digunakan sebesar 100 responden. 100 sampel yang diperoleh dari $89,5 \%$ dari jumlah populasi. Apabila subyeknya kurang dari 100, lebih baik diambil senua sehingga penelitiannya merupakan penelitian populasi. Tetapi, jika jumlah subyeknya besar, dapat diambil 10\%-15\% atau 20\%-25\% atau lebih, tergantung dari kemampuan peneliti dilihat dari:

a. Kemampuan peneliti dilihat dari waktu, tenaga dan dana.

b. Sempit luasnya wilayah dari setiap subyek, karena hal tersebut menyangkut banyak sedikitnya data.

c. Besar kecilnya resiko yang ditanggung oleh peneliti. Untuk penelitian yang resikonya besar, tentu saja jika sampel besar, hasilnya akan lebih baik (Arikunto, 2013).

Bertolak dari pendapat para ahli, maka peneliti menggunakan teknik sampel acak/random dalam mengambil data penelitian. Sesuai pendapat Arikunto maka peneliti mengambil data sebanyak 100 yang digunakan sebagai sampel yang diperoleh dari $89,5 \%$ dari jumlah seluruh populasi. Dalam penelitian ini, peneliti menggunakan yang $10 \%-15 \%$ atau $20 \%$ $25 \%$ dikarenakan jumlah sampel yang digunakan lebih besar.

\section{Instrumen dan Teknik Pengumpulan Data Instrumen}

Instrumen penelitian adalah alat- alat atau tes yang akan digunakan untuk mengumpulkan data guna mendukung dalam keberhasilan suatu penelitian (Sugiyono, 2014). Data yang terkumpul akan digunakan untuk menjawab masalah dalam penelitian dan untuk menguji hipotesis penelitian. Instrumen yang dipergunakan sebelumnya tidak diuji cobakan kepada sampel, melainkan diujikan kepada orang coba yang lain. Hal ini dimungkinkan akan mempengaruhi data yang dikumpulkan. 
Ada tiga langkah yang harus diperhatikan dalam menyusun instrument penelitian, yaitu: (a) mendefinisikan konstrak, (b) menyidik faktor, dan (c) menyusun butir pernyataan (Hadi, 1991).

Instrumen adalah alat pada waktu peneliti menggunakan sesuatu metode. Instrumen pengumpulan data adalah alat bantu yang dipilih dan digunakan oleh peneliti dalam kegiatannya mengumpulkan agar kegiatan tersebut menjadi sistematis dan dipermudah olehnya (Arikunto, 2013).

Instrumen diperlukan agar pekerjaan yang dilakukan lebih mudah dan hasilnya lebih baik, dalam arti lebih cermat, lengkap dan sistematis sehingga data lebih mudah diolah. Instrumen atau alat yang digunakan dalam penelitian ini berupa kuesioner. Kuesioner digunakan untuk menyelidiki pendapat subjek mengenai suatu hal atau untuk mengungkapkan kepada responden. Angket atau kuesioner adalah sejumlah pertanyaan atau peryataan yang digunakan untuk memperoleh informasi sampel dalam arti laporan pribadinya, atau hal-hal yang ia ketahui (Arikunto, 2013).

Angket dibedakan ke dalam tiga jenis, yaitu angket berstruktur (tertutup), angket setengah berstruktur (setengah tertutup), dan angket terbuka. Pertanyaan berstruktur dibuat dengan pertimbangan untuk menghimpun data kuantitatif. Pertanyaan setengah terstruktur dibuat dengan pertimbangan untuk menghimpun data kuantitatif, menghimpun data kualitatif, dan memberi keleluasaan terbatas kepada responden. Pertanyaan terbuka dimaksudkan untuk mendapatkan data kualitatif dan memberi keleluasaan penuh kepada responden.

Keuntungan menggunakan angket adalah:

1. Tidak memerlukan kehadiran peneliti.

2. Dapat dibagi secara serentak kepada banyak responden.
3. Dapat dijawab oleh responden menurut kecepatannya masingmasing, dan menurut waktu senggang responden.

4. Dapat dibuat anonym sehingga responden bebas jujur dan tidak malu untuk menjawab.

5. Pertanyaan dibuat sama untuk masingmasing responden (Arikunto, 2013).

Sedangkan kelemahan dari penggunaan angket adalah:

1. Responden dalam menjawab sering tidak teliti sehingga ada yang terlewatkan.

2. Seringkali sukar dicari validitasnnya.

3. Walaupun anonim kadang responden sengaja memberikan jawaban yang tidak jujur.

4. Sering tidak kembali jika dikirim lewat pos.

5. Waktu pengembaliannya tidak bersamaan (Arikunto, 2013).

\section{Teknik Pengumpulan Data}

Dalam penelitian ini menggunakan metode survey dan teknik pengumpulan datanya menggunakan angket (kuisioner). Angket yang digunakan merupakan jenis angket tertutup dengan alternatif jawaban menggunakan modifikasi analisis skala likert. Alasan menggunakan skala ini karena dengan skala ini akan menilai ketunggalan dimensi artinya, skala sebaiknya hanya mengukur satu dimensi saja dari variabel yang memiliki beberapa dimensi. Setiap pertanyaan yang dijawab "Setuju", diberi skor 4 dan jawaban "Setuju" diberi skor 3, jawaban "Tidak Setuju" diberi skor 2 dan jawaban "Sangat Tidak Setuju" diberi skor 1 .

\section{Validitas dan Reliabilitas Instrumen}

Skala Likert digunakan sebagai alternatif jawaban. Dengan menggunakan skala pengukuran tipe ini akan didapat jawaban yang tegas, yaitu ya-tidak, benar-salah, 
pernah-tidak pernah, positif-negatif, dan lain- lain. Data yang diperoleh dapat berupa data interval (dua alternatif). Jawaban dapat dibuat skor tertinggi empat dan skor terendah satu. Dalam penelitian ini jawaban "Setuju", "Tidak Setuju", "Sangat Setuju" dan "Sangat Tidak Setuju". Setiap pertanyaan yang dijawab "Setuju", diberi skor 4 dan jawaban "Setuju" diberi skor 3, jawaban "Tidak Setuju" diberi skor 2 dan jawaban "Sangat Tidak Setuju" diberi skor 1.

\section{Uji Validitas Instrumen (Tingkat}

\section{Kesahian Butir)}

Validitas adalah suatu ukuran yang menunjukkan tingkat-tingkat kevalidan atau kesahihan sesuatu instrumen tertentu. Suatu instrumen yang valid atau sahih mempunyai validitas yang tinggi. Uji validitas atau kesahihan butir harus melalui beberapa langkah sebelum menyatakan bahwa butir instrumen tersebut sahih atau gugur (Arikunto, 2013).

Adapun langkah-langkahnya menghitung skor faktor dari skor butir (Hadi, 1991):

1. Menghitung Korelasi Moment Tangkar antara butir dengan faktor

Korelasi product moment

$$
\mathrm{r}_{\mathrm{xy}}=\frac{N_{\Sigma} X Y-\left(\sum X\right)\left(\sum Y\right)}{\overline{\left\{N_{\Sigma} X^{2}-(\Sigma X)^{2}\right\}\left\{N_{\Sigma} Y^{2}-\left(\sum Y\right)^{2}\right\}}}
$$

Keterangan:

$\mathrm{X}=$ Skor rata-rata dari $\mathrm{X}$

$\mathrm{Y}=$ Skor rata-rata dari $\mathrm{y}$

$\mathrm{N}=$ Jumlah subjek uji coba

Sumber: (Arikunto, 2013)

Instrumen pada penelitian ini berupa kuesiner, yang terdiri dari 40 item pernyataan. Berdasarkan hasil uji validitas, secara ringkas disajikan pada tabel berikut ini.

Tabel 4. Hasil Uji Validitas Instrumen Penelitian

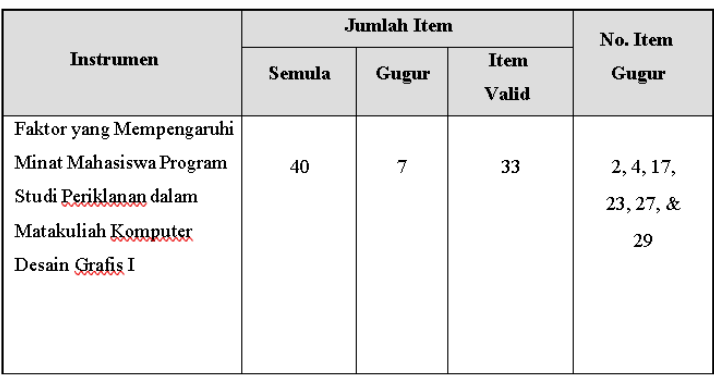

Tabel tersebut di atas menunjukkan bahwa dari 40 item pernyataan, 7 item dinyatakan gugur, yaitu item nomor: 2,4 , 11, 23, 27, dan 29; sehingga didapatkan 33 item yang valid. Dari 33 item yang valid tersebut, masih mewakili indikatorindikator dari Faktor yang Mempengaruhi Minat Mahasiswa Program Studi Periklanan dalam Matakuliah Komputer Desain Grafis I.

\section{Uji Reliabilitas Instrumen}

Reliabilitas menunjuk pada satu pengertian bahwa suatu instrumen cukup dapat dipercaya untuk digunakan sebagai alat pengumpul data karena instrumen tersebut sudah baik Pengujian reliabilitas dengan teknik Alpha dilakukan untuk jenis data angket atau bentuk uraian (Arikunto, 2013). Adapun rumus Alpha sebagai berikut:

Keterangan:

$\mathrm{r}_{11}=$ Reliabilitas instrumen

$\mathrm{k}=$ Banyaknya butir

pertanyaan/banyaknya soal

$\sum_{+}{ }^{2}=$ Jumlah Variabel Butir

$t^{2}=$ Varians Total

Hasil uji reliabilitas instrumen, secara ringkas disajikan pada tabel berikut ini :

Tabel 5. Hasil Uji Reliabilitas Instrumen Penelitian

\begin{tabular}{|l|c|c|}
\hline \multicolumn{1}{|c|}{ Instrumen } & $\begin{array}{c}\text { Koef. Alpha } \\
\left(\mathrm{r}_{11}\right)\end{array}$ & Keterangan \\
\hline $\begin{array}{l}\text { Faktor yang Mempengaruhi Minat Mahasiswa } \\
\text { Program Studi Periklanan dalam Matakuliah } \\
\text { KomputerDesain Grafis I }\end{array}$ & 0,765 & Reliabel \\
\hline
\end{tabular}


Berdasarkan tabel tersebut di atas, diketahui bahwa instrumen hambatan Dosen dalam pembelajaran Komputer Desain Grafis I memiliki tingkat reliabilitas (Alpha Cronbach) sebesar 0,765. Koefisien Alpha Cronbach berada pada interval pada patokan tingkat reliabilitas 0,80-1,00 dengan interpretasi sangat tinggi; dengan demikian instrumen Faktor yang Mempengaruhi Minat Mahasiswa Program Studi Periklanan dalam Matakuliah Komputer Desain Grafis I pada penelitian ini tingkat reliabilitasnya berada pada kategori sedang.

\section{Teknik Analisis Data}

Teknik analisis data yang dimaksud adalah untuk mencari jawaban atas pertanyaan yang dirumuskan sebelumnya. Berdasarkan jenis penelitiannya, penelitian ini deskriptif kuantitatif dimana menggunakan metode penelitian koesioner (angket). Data angket dianalisis menggunakan rumus:

$\mathrm{P}=\frac{\mathrm{f}}{\mathrm{N}} \times 100 \%$

Keterangan:

P: Angka Prosentase (\%)

f: Frekunsi yang sedang dicari presentasenya

$\mathrm{N}$ : Jumlah frekuensi/ banyaknya individu

\section{HASIL DAN PEMBAHASAN PENELITIAN \\ Hasil Penelitian}

Deskripsi data hasil penelitian ini dimaksudkan untuk menggambarkan hasil-hasil pengumpulan data yaitu tentang jawaban responden atas angket yang diberikan kepada responden yang mengukur Faktor yang Mempengaruhi Minat Mahasiswa Program Studi
Periklanan dalam Matakuliah Komputer Desain Grafis I. Dari gambaran ini dapat diketahui distribusi frekuesi dari data penelitian yaitu mengenai Faktor yang Mempengaruhi Minat Mahasiswa Program Studi Periklanan dalam Matakuliah Komputer Desain Grafis I.

Setelah data penelitian terkumpul dilakukan analisis dengan menggunakan teknik analisis deskriptif kuantitatif dengan persentase menggunakan bantuan komputer program windows excel. Dari analisis data tersebut dapat dilihat pada diagram batang dibawah ini :

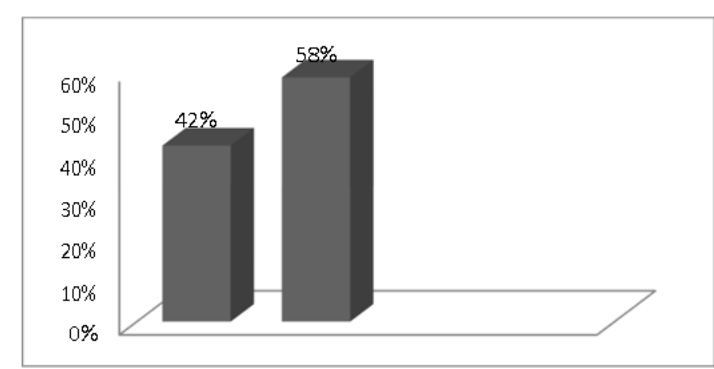

Gambar 1. Diagram batang Faktor yang Mempengaruhi Minat Mahasiswa Program Studi Periklanan dalam Matakuliah Kơkmpufer Đॄesain Grafis I fakterintern dan faktor extern

\section{Hasil Analisis Data Faktor Intern}

Dari analisis data dalam faktor intern diperoleh skor terendah (minimum) 32, skor tertinggi (maksimum) 49, rerata (mean) 39,75, nilai tengah (median) 38, nilai yang sering muncul (mode) 38, standar defiasi (SD) 3,15.

Setelah di jumlah dengan menggunakan rumus, hasil yang diperoleh bahwa Faktor yang Mempengaruhi Minat Mahasiswa Program Studi Periklanan dalam Matakuliah Komputer Desain Grafis I faktor intern adalah $41 \%$.

\section{Hasil Analisis Data Faktor Extern}

Dari analisis data dalam faktor extern diperoleh skor terendah (minimum) 44, skor tertinggi (maksimum) 73, rerata (mean) 57,03, nilai tengah (median) 56, 
nilai yang sering muncul (mode) 54, standar defiasi (SD) 5,85.

Setelah di jumlah dengan menggunakan rumus, hasil yang diperoleh bahwa Faktor yang Mempengaruhi Minat Mahasiswa Program Studi Periklanan dalam Matakuliah Komputer Desain Grafis I faktor extern adalah 59\%.

Dari analisis data perfaktor dapat dilihat pada diagram batang dibawah ini :

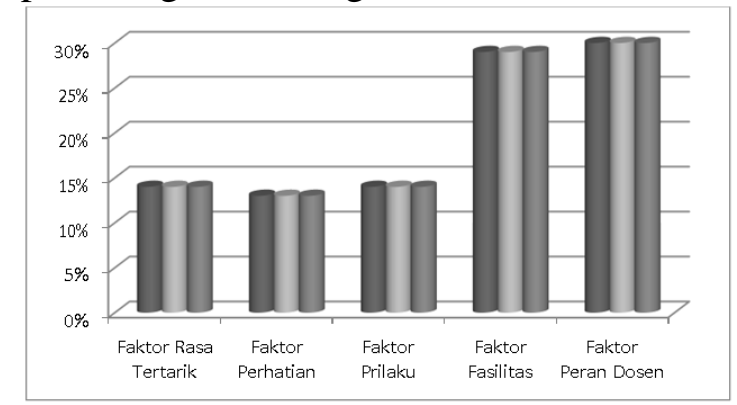

Gambar 2. Diagram batang Faktor yang Mempengaruhi Minat Mahasiswa Program Studi Periklanan dalam Matakuliah Komputer Desain Grafis I untuk data perfaktor

\section{Hasil Analisis Data Faktor Rasa Tertarik}

Dari analisis data dalam faktor rasa tertarik diperoleh skor terendah (minimum) 11, skor tertinggi (maksimum) 18, rerata (mean) 15,32, nilai tengah (median) 15, nilai yang sering muncul (mode) 15, standar defiasi (SD) 1,27.

Setelah di jumlah dengan menggunakan rumus, hasil yang diperoleh bahwa Faktor yang Mempengaruhi Minat Mahasiswa Program Studi Periklanan dalam Matakuliah Komputer Desain Grafis I faktor rasa tertarik adalah $15 \%$.

\section{Hasil Analisis Data Faktor Perhatian}

Dari analisis data dalam faktor perhatian diperoleh skor terendah (minimum) 7 , skor tertinggi (maksimum) 17, rerata (mean) 12,45, nilai tengah (median) 14 , nilai yang sering muncul (mode) 14 , standar defiasi (SD) 1,55.
Setelah di jumlah dengan menggunakan rumus, hasil yang diperoleh bahwa Faktor yang Mempengaruhi Minat Mahasiswa Program Studi Periklanan dalam Matakuliah Komputer Desain Grafis I faktor perhatian adalah $11 \%$.

\section{Hasil Analisis Data Faktor Prilaku}

Dari analisis data dalam faktor prilaku diperoleh skor terendah (minimum) 8 , skor tertinggi (maksimum) 19, rerata (mean) 14,93, nilai tengah (median) 15 , nilai yang sering muncul (mode) 15, standar defiasi (SD) 1,98.

Setelah di jumlah dengan menggunakan rumus, hasil yang diperoleh bahwa Faktor yang Mempengaruhi Minat Mahasiswa Program Studi Periklanan dalam Matakuliah Komputer Desain Grafis I faktor prilaku adalah $15 \%$.

\section{Hasil Analisis Data Faktor Fasilitas}

Dari analisis data dalam faktor fasilitas diperoleh skor terendah (minimum) 21, skor tertinggi (maksimum) 38, rerata (mean) 28,36, nilai tengah (median) 29, nilai yang sering muncul (mode) 29, standar defiasi (SD) 3,47.

Setelah di jumlah dengan menggunakan rumus, hasil yang diperoleh bahwa Faktor yang Mempengaruhi Minat Mahasiswa Program Studi Periklanan dalam Matakuliah Komputer Desain Grafis I faktor fasilitas adalah $28 \%$.

\section{Hasil Analisis Data Faktor Peran Dosen}

Dari analisis data dalam faktor peran dosen diperoleh skor terendah (minimum) 21, skor tertinggi (maksimum) 37, rerata (mean) 28,65, nilai tengah (median) 29, nilai yang sering muncul (mode) 29, standar defiasi (SD) 3,47.

Setelah di jumlah dengan menggunakan rumus, hasil yang diperoleh bahwa Faktor yang Mempengaruhi Minat Mahasiswa Program Studi Periklanan dalam Matakuliah Komputer Desain Grafis I faktor peran dosen adalah $31 \%$. 


\section{Pembahasan}

Berdasarkan data hasil penelitian, maka dapat diketahui bahwa Faktor yang Mempengaruhi Minat Mahasiswa Program Studi Periklanan dalam Matakuliah Komputer Desain Grafis I termasuk dalam kategori tinggi adalah faktor external sebesar $59 \%$ dan faktor internal rendah sebesar $41 \%$.

Sedangkan dari data perfaktor, data yang paling tinggi adalah faktor peran dosen sebesar $31 \%$, faktor fasilitas $28 \%$, faktor rasa tertarik sebesar $15 \%$, faktor prilaku sebesar $15 \%$ dan yang rendah adalah faktor perhatian sebesar $11 \%$.

Faktor yang Mempengaruhi Minat Mahasiswa Program Studi Periklanan dalam Matakuliah Komputer Desain Grafis I tidak terlepas dari faktor-faktor yang digunakan yaitu faktor intern dan faktor ekstern. Adapun pembahasan masing-masing faktor adalah sebagai berikut:

\section{Faktor Intern}

Faktor intern mempengaruhi minat mahasiswa untuk pembelajaran Komputer Desain Grafis I. Faktor tersebut berasal dari diri mahasiswa itu sendiri. Setelah diadakan penelitian maka Faktor yang Mempengaruhi Minat Mahasiswa Program Studi Periklanan dalam Matakuliah Komputer Desain Grafis I melalui faktor intern pada penelitian ini yakni sebesar $41 \%$ lebih kecil dari faktor extern.

\section{Faktor Ekstern}

Faktor ekstern merupakan faktor pendorong dari luar mahasiswa untuk melaksanakan pembelajaran Komputer Desain Grafis I agar berjalan secara maksimal. Faktor yang Mempengaruhi Minat Mahasiswa Program Studi Periklanan dalam Matakuliah Komputer Desain Grafis I melalui faktor ekstern pada penelitian ini yakni sebesar 59\% lebih besar dari faktor intern.
Dari hasil tersebut diketahui bahwa berdasarkan faktor ekstern, Faktor yang Mempengaruhi Minat Mahasiswa Program Studi Periklanan dalam Matakuliah Komputer Desain Grafis I dalam katagori tinggi, hal tersebut dikarenakan sarana pendukung yang digunakan untuk kegiatan pembelajaran Komputer Desain Grafis I sangat memadai. Selain sarana, materi dari dosen dan mahasiswa juga sangat berpengaruh terhadap berlangsungnya proses pembelajaran.

Faktor yang Mempengaruhi Minat Mahasiswa Program Studi Periklanan dalam Matakuliah Komputer Desain Grafis I melalui faktor intern dalam indikator :

a. Rasa Tertarik, dalam suatu kegiatan pembelajaran, mahasiswa harus merasa tertarik dengan Desain Grafis, karena sangat berpengaruh dalam proses pembelajaran. Apabila tidak ada mahasiswa yang tertarik dengan Desain Grafis maka kegiatan belajar mengajar tidak akan terjadi. Dari hasil tersebut dapat diartikan bahwa indikator faktor rasa tertarik yakni sebesar $15 \%$, mahasiswa tidak tertarik dengan pembelajaran Komputer Desain Grafis I. Mahasiswa mengambil matakuliah Komputer Desain Grafis I bukan karena mereka begitu berminat mengambil matakuliah Komputer Desain Grafis I, dikarenakan karena faktor dosen yang menurut mereka mudah untuk mendapatkan nilai yang bagus.

b. Perhatian, perhatian dari mahasiswa akan sangat membuat pembelajaran Komputer Desain Grafis I akan berjalan dengan lancar dan optimal. Berdasarkan indikator faktor perhatian yakni sebesar $11 \%$. Dari hasil tersebut dapat diartikan bahwa faktor perhatian dari mahasiswa tidak berpengaruh terhadap berlangsungnya pembelajaran Komputer 
Desain Grafis I. Dimana perhatian dari mahasiswa sangat berpengaruh besar terhadap proses pembelajaran Komputer Desain Grafis I tersebut.

c. Prilaku, prilaku belajar dari mahasiswa akan sangat membantu pembelajaran Komputer Desain Grafis I sehingga bisa berjalan dengan lancar dan optimal. Berdasarkan indikator faktor prilaku yakni sebesar $15 \%$. Dari hasil tersebut dapat diartikan bahwa faktor prilaku dari mahasiswa tidak begitu berpengaruh terhadap berlangsungnya pembelajaran Komputer Desain Grafis I.

Faktor yang Mempengaruhi Minat Mahasiswa Program Studi Periklanan dalam Matakuliah Komputer Desain Grafis I melalui faktor extern dalam indikator :

a. Fasilitas, dalam suatu kegiatan pembelajaran penjas dan dengan fasilitas yang memadai akan membuat pembelajaran berjalan dengan lancar, karena fasilitas ini sangat berpengaruh dalam proses pembelajaran. Apabila kurangnya fasilitas yang disediakan pihak kampus akan membuat pembelajaran Komputer Desain Grafis I ini terganggu. Berdasarkan hasil penelitian diketahui indikator faktor fasilitas yakni sebesar 28\%. Mahasiswa begitu tertarik dengan pembelajaran Komputer Desain Grafis I. Dengan banyaknya sarpras yang dimiliki oleh pihak kampus UBSI. Jadi, dalam proses pembelajaran Komputer Desain Grafis I ini sangat begitu mendukung.

b. Peran Dosen, Peran dosen ini sangat membantu mahasiswa dalam pembelajaran Komputer Desain Grafis I. Berdasarkan indikator faktor peran dosen lebih tinggi daripada faktor yang sebelumnya yakni sebesar $31 \%$. Dari hasil tersebut dapat diartikan bahwa faktor peran dosen sangat begitu diharapkan dalam membantu mahasiswanya melaksanakan pembelajarn Komputer
Desain Grafis I dan teknik-teknik dalam pembelajaran Komputer Desain Grafis I. Dan peran dosen ini akan sangat membantu mahasiswa, dengan sikap dan sifat dosen pada saat mengajar tersebut. Sehingga yang dirasakan dari mahasiswa dari segi peran dosen pada katagori tinggi. Dimana peran dosen sebagai pengajar sangat berpengaruh besar terhadap proses pembelajaran Komputer Desain Grafis I dan sebagai contoh untuk mahasiswanya. Faktor peran dosen juga sangat berpengaruh terhadap minat mahasiswa, karena dosen yang mengajar begitu mudah untuk mereka mendapatkan nilai yang bagus dan dapat cepat lulus.

\section{KESIMPULAN}

Berdasarkan hasil penelitian dan pembahasan yang telah diuraikan dalam bab sebelumnya, penulis dapat menarik kesimpulan sebagai berikut: Faktor yang Mempengaruhi Minat Mahasiswa Program Studi Periklanan dalam Matakuliah Komputer Desain Grafis I yakni faktor eksternal sebesar 59\% lebih tinggi dari faktor internal yakni sebesar $41 \%$. Sedangkan dari data perfaktor, data yang paling tinggi adalah faktor peran dosen sebesar $31 \%$, faktor fasilitas $28 \%$, faktor rasa tertarik sebesar $15 \%$, faktor prilaku sebesar $15 \%$ dan yang rendah adalah faktor perhatian sebesar $11 \%$.

\section{DAFTAR PUSTAKA}

Abror, A. R. (1993). Psikologi Pendidikan (Cetakan Ke). Yogyakarta: P.T. Tiara Wacana Yogya.

Arikunto, S. (2013). Prosedur Penelitian: Suatu Pendekatan Praktik. Jakarta: Rineka Cipta.

Gunarto. (2007). Minat Siswa Kelas Atas SDN Cangkringan Mengikuti Kegiatan Ekstrakurikuler Tenis Meja Tahun Pelajaran 2007/2008. FIK Universitas Negeri Yogyakarta, 
Yogyakarta.

Hadi, S. (1991). Analisis Butir Untuk

Instrumen Skala BASICA.

Yogyakarta: Andi Offset.

Haditono, S. R. (2007). Psikologi

Perkembangan. Yogyakarta: Gadjah

Mada University Press.

Hurlock, E. B. (1978). Perkembangan

Anak, Jilid 2 (Edisi Keen). Jakarta:

P.T Erlangga.

Mappiare, A. (1994). Psikologi Remaja.

Surabaya: Usaha Nasional.

Periklanan, P. (2017). Dokumen

Kurikulum 2017. Jakarta.

Slameto. (2010). Belajar dan Faktorfaktor yang Mempengaruhinya.

Jakarta: PT. Rineka Cipta.

Sugiyono. (2014). Metode Penelitian

Kuantitatif, Kualitatif Dan $R \& D$

(22nd editi). Bandung: CV Alfabeta.

Sujanto, A. (2008). Psikologi Umum.

Yogyakarta: Bumi Aksara.

Suryosubroto, B. (1988). Dasar-dasar

Psikologi Untuk Pendidikan Di

Sekolah. Jogjakarta: P.T Prima

Karya.

Zakaria. (2020). Adobe Photoshop CS6.

Retrieved from

https://www.nesabamedia.com/downl

oad-adobe-photoshop-cs6/

\section{BIODATA PENULIS}

\section{Jusuf Fadilah, M.I.Kom}

Lahir di Jakarta, 9 Februari 1987, sebagai

Ketua Prodi Periklanan di Program Studi

Periklanan, Fakultas Komunikasi dan

Bahasa UBSI.

\section{Dina Andriana, S.Sos, M.I.Kom}

Lahir di Sungai Pakning, 21 April 1983.

Sebagai dosen tetap di Program Studi

Periklanan, Fakultas Komunikasi dan

Bahasa UBSI.

\section{Widarti, M.I.Kom}

Lahir di Jakarta, 21 Juni 1987, sebagai dosen tetap di Program Studi Periklanan dan anggota tim PPPM UBSI. 